\title{
Akreditasi Perguruan Tinggi dan Kebijakan Merdeka Belajar-Kampus Merdeka: Sebuah Pengalaman dan Harapan
}

\section{(Higher Education Accreditation and Policy for Independent Learning-Independent Campus: An Experience and Hope)}

\author{
Nuryadi Wijiharjono \\ Email: nurwiha@gmail.com \\ ORCID: https://orcid.org/0000-0003-0089-7586
}

\begin{abstract}
$\underline{\text { Abstrak }}$
Tujuan artikel ini adalah untuk mengungkapkan pengalaman dalam mengikuti perjalanan akreditasi perguruan tinggi, dan harapannya pada kebijakan baru tentang Merdeka Belajar-Kampus Merdeka (MBKM). Dengan jumlah perguruan tinggi lebih dari 4000, dan hanya sedikit yang benar-benar bermutu dan berhasil menjadi pusat-pusat keunggulan, taruhannya adalah nasib generasi muda dan masa depan Indonesia. Apalagi universitas-universitas bermutu tersebut lebih banyak berada di Pulau Jawa, bukan hanya kesenjangan mutu yang semakin melebar, tetapi juga akses terhadap pendidikan tinggi bagi seluruh rakyat Indonesia menjadi timpang. Kebijakan MBKM, dengan sedikit catatan, dapat menjadi solusi alternatif untuk pendidikan abad 21.
\end{abstract}

Kata kunci: akreditasi, perguruan tinggi, kebijakan, Indonesia. 


\begin{abstract}
$\underline{\text { Abstract }}$
The purpose of this article is to reveal the experiences of the higher education accreditation model and expectations of the freedom to learn policy or "Merdeka BelajarKampus Merdeka" (MBKM). Indonesia has more than 4000 higher education institutions that are building quality to educate the nation's life. But only a few of these managed to become centers of excellence. There has been a widening quality gap between universities in Java and outside Java. Without radical policies in the higher education sector, the future of the young generation will be threatened. MBKM policy, with a few notes, can be an alternative solution for the $21^{\text {st }}$ century.
\end{abstract}

Keywords: accreditation, higher education, policy, Indonesia.

\title{
A. Pengantar
}

Alhamdulillah, bersyukur setelah sekian lama terjerembab dalam kejumudan administrasi dan birokrasi, muncul sebuah paket kebijakan pendidikan (Permendikbud Nomor 3/2020) yang diharapkan mampu menggairahkan dan memberi harapan bagi pengelolaan perguruan tinggi dan penyelenggaraan pendidikan tinggi di Indonesia. ${ }^{1}$ Bukan rahasia lagi bahwa beban pekerjaan administratif-birokratis, termasuk akreditasi, telah banyak menguras sumber daya perguruan tinggi yang semestinya dapat digunakan untuk peningkatan mutu secara substantif. Tata kelola perguruan tinggi yang masih bercorak sentralistik juga turut memboroskan sumber daya maupun asset yang, jika dikelola dengan tepat, dapat dipergunakan untuk kepentingan pendidikan masyarakat secara lebih luas. Dengan memberi kebebasan dan kesempatan kepada mahasiswa untuk mengakses sumber-sumber pengetahuan sesuai dengan minat, bakat, dan kemajuan

\footnotetext{
${ }^{1}$ Peraturan Menteri Pendidikan dan Kebudayaan RI Nomor 3 Tahun 2020 tentang Standar Nasional Pendidikan Tinggi, yang diundangkan pada tanggal 28 Januari 2020. Lihat juga: SIARAN PERS Nomor: 010/Sipres/A6/I/2020 https://www.kemdikbud.go.id/main/blog/2020/01/luncurkan-kampus-merdekamendikbud-sekarang-akreditasi-sifatnya-sukarela
} 
zaman, kebijakan Merdeka Belajar-Kampus Merdeka (MBKM) akan mengubah wajah pendidikan tinggi secara nasional.

Terdapat empat poin dalam kebijakan MBKM, yaitu: (1) pembukaan program studi baru; (2) sistem akreditasi perguruan tinggi; (3) perguruan tinggi negeri badan hukum; (4) hak belajar tiga semester di luar program studi. Tulisan ini hanya fokus pada dua hal, yaitu akreditasi dan hak belajar di luar program studi. Walaupun saat ini akreditasi bersifat sukarela (fakultatif), dalam konteks penjaminan mutu, peranannya tetap penting dan bernilai untuk kepentingan akuntabilitas, transparansi, dan rekognisi pada level nasional bahkan internasional. Sudah tentu implementasi kebijakan akreditasi dan gagasan "freedom to learn" melalui kebijakan MBKM yang baru setahun berjalan, belum dapat dilihat hasilnya. Apalagi kebijakan tersebut secara fundamental berimplikasi pada perubahan kurikulum yang hasilnya baru terlihat beberapa tahun kemudian. Ada waktunya nanti untuk menanggapi secara kritis atas sebuah kebijakan. Untuk saat ini, di masa pandemi Covid-19, lebih baik menjaga kesehatan dan membangun solidaritas seraya menyelamatkan keberlangsungan pendidikan nasional secara kreatif.

Secara teoretis, konsep merdeka belajar (freedom to learn) yang berpusat pada diri peserta didik sebagai subyek pendidikan (learner centered education), sudah lama dikenal dalam dunia pendidikan. Jika prinsip merdeka belajar dilaksanakan secara konsisten sejak pertengahan abad lalu misalnya, sebagaimana pernah diperkenalkan oleh Ki Hajar Dewatara dan para pendidik humanis lainnya, maka boleh jadi pendidikan nasional kita keadaannya akan lebih baik. Namun untuk tetap optimis sebagai manusa merdeka, ibarat nasi sudah menjadi bubur, maka kita bikin bubur ayam saja sekalian. Lebih enak rasanya!

Dalam kondisi ketidakpastian, apalagi dalam keadaan darurat wabah, improvisasi perlu dilakukan. Apalagi kebijakan MBKM bukanlah sebuah improvisasi dalam masa pandemi. Pendidikan tidak boleh berhenti, yang penting masih ada kejujuran dan ketulusan sesama warga bangsa. Tidak ada orang yang mencuri kesempatan dalam kesempitan. Penting diingat, dalam zaman diktator industri digital yang telah memaksa manusia untuk tunduk dan patuh kepada sistem Big Data, entah yang dikendalikan oleh 
korporasi nasional maupun ekonomi politik internasional, apa pun bisa terjadi, termasuk pada sektor pendidikan.

Sedikitnya terdapat tiga alasan mengapa akreditasi perguruan tinggi dalam konteks kebijakan "MBKM" menarik untuk dikaji. Pertama, adalah karena alasan normatif. Kebijakan harus mengabdi kepada keadilan, tidak boleh ada diskriminasi. ${ }^{2}$ Hasil penelitian kebijakan pendidikan di Amerika Serikat misalnya, menemukan bahwa pengaruh kelompok kepentingan, terutama kelompok bisnis dan asosiasi tradisional, cenderung dominan terhadap proses pembuatan kebijakan. ${ }^{3}$ Kedua, adalah karena alasan teoretis, di mana semua pemangku kepentingan (stakeholder) dalam pembuatan kebijakan pendidikan tidak boleh diabaikan, harus dilibatkan. Ketiga, adalah karena alasan pragmatis, bahwa semua kebijakan pendidikan harus berorientasi pada peningkatan mutu manusia Indonesia dan kemanfaatan bagi kepentingan nasional.

Untuk itu, dalam kerangka analisis kebijakan pendidikan tinggi dalam konteks MBKM, tulisan ini dibagi dalam beberapa bagian melalui serangkaian pertanyaan begini: Pertama, bagaimana perkembangan akreditasi di Indonesia, termasuk kinerja BAN-PT, sebelum dan sesudah tahun 2012, yakni ketika Undang-Undang Republik Indonesia No. 12 Tahun 2012 tentang Pendidikan Tinggi mulai diberlakukan. Kedua, apa pelajaran yang dapat diambil dalam konteks kebijakan MBKM? Ketiga, kesimpulan apa yang dapat ditarik dari pembahasan tersebut?

\section{B. Perkembangan Model Akreditasi Perguruan Tinggi (PT)}

Meskipun kesejarahan perguruan tinggi di dunia berbeda-beda tetapi tuntutannya tetap sama, yaitu masalah mutu lulusan dan akreditasi. Jika dimunculkan sebuah pertanyaan ini: Mengapa kampus-kampus banyak pergururuan tinggi di Amerika Serikat (AS) besar-besar dan luas-luas? Jawabanya adalah sejarah. Zaman itu, bahkan sampai sekarang, hanya sedikit orang yang mampu bersekolah di perguruan tinggi swasta seperti

\footnotetext{
${ }^{2}$ Fattah, Nanang, “Sesi Kuliah Kajian Kebijakan Pendidikan”, PPs UIKA, Bogor (16 Oktober 2010).

${ }^{3}$ Lihat misalnya, Opfer, V. D., Tamara V.Y., dan Lance D.F., "Politics of Interest: Interest Groups and Advocacy Coalitions in American Education," dalam Cooper, Bruce S., James G. Cibulka, dan Lance. Fusarelli D. 2008. Handbook of Education Politics and Policy, New York \& London: Routledge, hlm. 195-210.
} 
Universitas Harvard. Maka munculah kebijakan yang radikal dan monumental yaitu apa yang kemudian dikenal sebagai The 1862 Morrill Act atau 1862 Land-Grand Universities. $^{4}$

Intinya, negara sejak awal menyadari bahwa pendidikan adalah kunci masa depan bangsa dan paham bagaimana membuat dan mengimplementasikan kebijakan. Oleh karena itu, melalui undang-undang tersebut, negara membagi-bagikan ribuan hehktar tanah kepada masyarakat untuk kepentingan mendirikan universitas-universitas. Massachusetts Institute of Technology (MIT) yang kesohor itu adalah salah satu contohnya. Banyak di antara perguruan tinggi tersebut yang kini menjadi mandiri dan kaya karena keberhasilan mereka dalam mengelola asset (endowment asset management). Itulah yang menyebabkan mengapa sumber keuangan dari mahasiswa (tuition fee) relatif kecil dibandingkan dengan sumber keuangan lainnya (endowment asset). Bagi mereka, isian borang akreditasi untuk sumber pembiayaan dari luar mahasiswa misalnya, bukan lagi menjadi masalah yang rumit.

Akreditasi adalah kegiatan penilaian kelayakan program dalam satuan pendidikan berdasarkan kriteria yang telah ditetapkan. ${ }^{5}$ Akreditasi dilakukan untuk menentukan kelayakan program dan satuan pendidikan pada jalur pendidikan formal dan nonformal pada setiap jenjang dan jenis pendidikan. ${ }^{6}$ Pelaksanaan akreditasi, menurut Kamanto Sunarto, dilakukan sejak tahun 1997 untuk Program Pendidikan Sarjana, dan sejak tahun 1999 untuk Program Pendidikan Magister. Sedangkan akreditasi untuk Program Pendidikan Diploma (I, II, III, IV) dan Program Pendidikan Doktor dimulai sejak tahun 2001. Kecuali akreditasi untuk program studi dan program profesi (sejak 2008), BAN-PT juga melakukan akreditasi untuk insitusi perguruan tinggi (AIPT), yang dimulai sejak tahun $2007 / 2008 .^{7}$

Perguruan tinggi yang pada umumnya berbentuk universitas, menurut Surakhmad, merupakan sebuah lembaga pembangunan yang karena mempunyai peran spesifik

\footnotetext{
${ }^{4}$ The Land-Grant Tradition. 2012. Washington DC: Association of Public and Land-Grant Universities.

${ }^{5}$ UU Sistem Pendidikan Nasional No. 20 Th. 2003 (Pasal 1 Ayat 22).

${ }^{6}$ UU No. 20/2003 tentang Sistem Pendidikan Nasional (Pasal 60 ayat 1 dan ayat 2)

${ }^{7}$ Sunarto, Kamanto. 2009. Kebijakan BAN-PT 2006-2011 (Bahan Presentasi), Jakarta: BAN-PT.
} 
memerlukan pengelolaan professional, yang tidak mudah dipahami oleh mereka yang bersinggungan dengan universitas hanya secara okasional atau insidental. Keterbatasan kemampuan dan kemauan, menyebabkan peran dan persyaratan khusus itu terdesak ke samping. Sebagai ganti yang menonjol adalah konsideran lain, yang umumnya tidak seberapa relevan dengan aspirasi pengembangan sumber daya manusia terdididik untuk pembangunan. Ada yang dominan bermotif politik, motif kedaerahan, profit komersial, dan lain-lain. ${ }^{8}$

Dalam pandangan Surakhmad, usaha pemerintah untuk mendorong kemajuan internal universitas dengan jalan mengadakan badan akreditasi, dapat dimengerti. Idealnya, akreditasi hendaknya datang dari bawah, sebagai perwujudan tumbuhnya kesadaran dan kemauan universitas sendiri untuk membenahi diri dan untuk memberikan yang terbaik kepada masyarakat umumnya, perkembangan ilmu dan teknologi khussnya. Pengakuan sebenarnya mengenai mutu sebuah universitas ditentukan pertama oleh komunitas ilmiah dan masyarakat pengguna, bukan idealnya oleh administrasi pemerintah. $^{9} \quad$ Menurut Tilaar, upaya-upaya selama untuk memperbaiki manajemen pendidikan tinggi memang sudah mulai diaksanakan seperti peninjauan kembali kelembagaan dan fungsi BAN, kemitraan yang realistik antara PTN dan PTS dengan memberikan keleluasaan bagi PTS untuk berkembang, pembukaan program-program studi tanpa meminta restu dari pemerintah dan sebagainya. ${ }^{10}$ Hanya saja, dalam implementasinya seringkali tidak konsisten.

Masalah akreditasi menuntut visi baru dari lembaga akreditasi yang ada. BAN yang ada dewasa ini, menurut Tilaar, perlu direposisi agar menjadi lembaga yang independen dengan mengikutsertakan organisasi-organisasi profesi bahkan dapat mengikutsertakan lembaga-lembaga akreditasi tingkat internasional. Dengan demikian, kita merintis jalan untuk membenahi pendidikan tinggi nasional ke arah research

\footnotetext{
8 Surakhmad, Winarno. 2009. Pendidikan Nasional; Strategi dan Tragedi. Jakarta: Kompas, hlm. 391.

${ }^{9}$ Surakhmad, Winarno. 2009. Pendidikan Nasional; Strategi dan Tragedi. Jakarta: Kompas, hlm. 439.

10 Tilaar, H.A.R. 2009. Kekuasaan dan Pendidikan. Jakarta: Rineka Cipta. hlm. 304.
} 
university yang diidam-idamkan. ${ }^{11}$ Meskipun harus diakui bahwa selama sepuluh tahun terakhir ini pun perkembanganya masih terasa lamban, dan untuk sebagian aturan juga masih cenderung birokratis.

Dalam perspektif Total Quality Management (TQM), akreditasi perguruan tinggi merupakan salah satu cara yang dianggap mampu meningkatkan mutu pendidikan tinggi. Oleh karena itu, sebelum muncul paket kebijakan "MBKM", setiap perguruan tinggi wajib melakukan akreditasi sebagai pelaksanaan sistem penjaminan mutu eksternal. Di Indonesia, akreditasi perguruan tinggi dilakukan oleh Badan Akreditasi NasionalPerguruan Tinggi (BAN-PT). ${ }^{12}$ Sejak berdiri hingga kini, BAN-PT telah melakukan akreditasi terhadap ribuan program studi yang diselenggarakan oleh ribuan perguruan tinggi. Manfaat akreditasi bagi pemangku kepentingan (stakeholders), menurut Kamanto Sunarto (2010), antara lain bermanfaat untuk menjamin mutu perguruan tinggi (PT) dan program studi (PS), menjamin mutu tenaga kerja, dan informasi untuk pembinaan PT/PS seperti penentuan beasiswa/hibah. ${ }^{13}$ Upaya perbaikan terhadap pelaksanaan akareditasi juga sudah dilakukan. Walaupun secara substantif masih banyak yang harus disempurnakan untuk mampu mewujudkan mutu pendidikan tinggi.

\section{Model Akreditasi PT Sebelum 2012}

Dasar hukum kebijakan akreditasi jurusan/program studi sebelum diberlakukannya UU Nomor 12/2012 tentang Pendidikan Tinggi adalah:

a) Undang-Undang RI. No. 20 Tahun 2003 tentang Sistem Pendidikan Nasional;

b) Undang Undang RI. No. 14 Tahun 2005 tentang Guru dan Dosen;

c) Peraturan Pemerintah RI. No. 19 Tahun 2005 tentang Standar Nasional Pendidikan;

d) Peraturan Mendiknas No. 28 Tahun 2005 tentang BAN-PT.

\footnotetext{
11 Tilaar, H.A.R. 2009. Kekuasaan dan Pendidikan. Jakarta: Rineka Cipta.hlm. 309.

12 http://edukasi.kompas.com/read/2010/10/22/16215327/2.922.Perguruan.Tinggi.Tanpa.Akreditasi, diakses 12/1/2011.

${ }^{13}$ Sunarto, Kamanto. 2009. Kebijakan BAN-PT 2006-2011 (Bahan Presentasi), Jakarta: BAN-PT.
} 
Sebelum diberlakukan model akreditasi dengan menggunakan 9 (sembilan) standar atau sembilan kriteria per April 2019 seperti yang berlaku saat ini, terdapat 7 (tujuh) standar yang dijadikan penilaian akreditasi oleh BAN-PT, yaitu penilaian berdasarkan standar mahasiswanya, dosen, infrastruktur meliputi sarana dan prasarana, kurikulum, penelitian, pengabdian pada masyarakat, serta prospek kerja alumni. ${ }^{14}$ Sedangkan instrumen yang digunakan dalam melaksanakan akreditasi perguruan tinggi, sebagaimana disebutkan pada Surat Edaran BAN-PT No. 609/BANPT/Edaran/III/2009, tanggal 10 Maret 2009, khususnya untuk program studi (S-1) adalah:

1. Buku 1-Naskah Akademik Akreditasi Program Studi Sarjana.

2. Buku 2-Standar dan Prosedur Akreditasi Sarjana.

3. Buku 3A-Borang Akreditasi Sarjana.

4. Buku 3B-Borang Fakultas/Sekolah Tinggi.

5. Buku 4-Panduan Pengisian Instrumen Akreditasi S-1.

6. Buku 5-Pedoman Penilaian Instrumen Akreditasi Program Sarjana.

7. Buku 6-Matriks Penilaian Instrumen Akreditasu Program Studi S-1.

8. Pedoman Evaluasi Diri.

9. Matriks Penilaian Laporan Evaluasi Diri 2009. ${ }^{15}$

Dalam perspektif teori kebijakan, kebijakan akreditasi perguruan tinggi di Indonesia sebelum terbitnya Permendikbud Nomor 3/2020, menggunakan pendekatan dari atas (top down) dan bercorak sentralistik. Sebab, kebijakan akreditasi muncul dari inisiatif pemerintah bukan atas dasar kesadaran dari pengelola perguruan tinggi. Sedangkan lembaga yang diakui sebagai pelaksana kebijakan akreditasi perguruan tinggi hanya satu, yang awalnya juga bentukan pemerintah, yakni BAN-PT. ${ }^{16}$ Tugas BAN-PT

\footnotetext{
${ }^{14}$ http://edukasi.kompas.com/read/2010/10/22/1912219/1.500.Program.Studi.Belum.Terakreditasi, diakses $12 / 1 / 2011$

${ }^{15}$ http://ban-pt.depdiknas.go.id/bb09/se20090310-609.pdf, diakses 21/1/2011.

${ }^{16}$ Akreditasi terhadap program dan satuan pendidikan dilakukan oleh Pemerintah dan/atau lembaga mandiri yang berwenang sebagai bentuk akuntabilitas publik UU No. 20/2003 tentang Sistem Pendidikan Nasional (Pasal 60 ayat 2).
} 
adalah merumuskan kebijakan operasional, melakukan sosialisasi kebijakan, dan melaksanakan akreditasi perguruan tinggi. ${ }^{17}$

Sedangkan fungsi BAN-PT, sebagaimana diatur dalam Permendiknas 28/2005, pasal 8, adalah:

(1) merumuskan kebijakan dan menetapkan akreditasi perguruan tinggi;

(2) merumuskan kriteria dan perangkat akreditasi perguruan tinggi untuk diusulkan kepada Menteri;

(3) melaksanakan sosialisasi kebijakan, kriteria, dan perangkat akreditasi perguruan tinggi;

(4) melaksanakan dan mengevaluasi pelaksanaan akreditasi perguruan tinggi;

(5) memberikan rekomendasi tentang tindak lanjut hasil akreditasi;

(6) mengumumkan hasil akreditasi perguruan tinggi secara nasional;

(7) melaporkan hasil akreditasi perguruan tinggi kepada Menteri; dan

(8) melaksanakan ketatausahaan BAN-PT.

Dalam menjalankan tugasnya, BAN-PT dibantu oleh tenaga penilai atau asesor dari kalangan akademis. Menurut Kamanto Sunarto, saat ini (2010) sudah ada 1.400 asesor di seluruh Indonesia. Para asesor atau tim penilai tersebut harus berasal dari kalangan ahli di program studi yang bersangkutan seperti mantan rektor atau guru besar, dan doktor. Menurutnya, saat ini terdapat 400 asesor dengan beban 200 program studi untuk dinilai. Tiap satu program studi dinilai oleh dua asesor. ${ }^{18}$

Pelaksanaan akreditasi, sebagaimana diatur dalam Peraturan Menteri Pendidikan Nasional RI No. 28 Tahun 2005 (Pasal 10), pada program dan/atau satuan pendidikan tinggi dilaksanakan setiap 5 (lima) tahun sekali. Pelaksanaan akreditasi dapat dilakukan kurang dari 5 (lima) tahun apabila perguruan tinggi yang bersangkutan mengajukan permohonan untuk diakreditasi ulang.

\footnotetext{
17 Tugas dan Fungsi BAN-PT (Permendiknas 28/2005), pasal 8.

${ }^{18} \mathrm{http}: / /$ edukasi.kompas.com/read/2010/10/22/1912219/1.500.Program.Studi.Belum.Terakreditasi, diakses 12/1/2011.
} 
Menurut Peraturan Menteri Pendidikan Nasional RI No. 28 Tahun 2005 (Pasal 12), BAN-PT dapat mencabut atau menurunkan status akreditasi program studi atau satuan pendidikan sebelum berakhirnya masa berlaku akreditasi apabila:

(1) program studi atau satuan pendidikan tinggi yang bersangkutan terbukti memberikan data dan/atau informasi yang tidak benar kepada badan akreditasi;

(2) sampai batas waktu yang ditetapkan, program studi atau satuan pendidikan tinggi yang memperoleh akreditasi kondisional tidak memenuhi kondisionalitas yang melekat pada status akreditasi; dan

(3) terjadi peristiwa luar biasa yang menimpa program studi atau satuan pendidikan tinggi yang bersangkutan sehingga status akreditasi yang melekat pada program studi atau satuan pendidikan tersebut tidak lagi mencerminkan tingkat kelayakannya.

Proses akreditasi perguruan tinggi sebelum April 2019 sebagai upaya penjaminan mutu secara ekternal, menurut pengalaman penulis, ${ }^{19}$ dilaksanakan melalui tiga tahap ini: Pertama, adalah tahap desk evaluation. Pada tahap ini yang dilakukan adalah pengisian borang/evaluasi diri/portovolio. Di masa awal kebijakan akreditasi, pengisian tersebut harus disertai lampiran data. Untuk saat ini, penyerahan lampiran data dilalukan pada saat proses visitasi. Kedua, adalah tahap field evaluation (visitasi). Tahap ini merupakan kunjungan asesor di mana program studi berada. Tujuannya adalah melakukan verifikasi terhadap data yang telah diisi pada tahap pertama. Yang terakhir, ketiga, adalah tahap reevaluation, yakni tahap penjelasan tim asesor terhadap penilaian akhir sebuah program studi.

Menurut Eduards Tandelilin, meskipun penilaian akreditasi dilakukan oleh tim asesor BAN-PT, tetapi yang memutuskan terakreditasi atau tidaknya sebuah perguruan tinggi dan program studi tetap di tangan Badan Akreditasi Nasional Perguruan Tinggi (BAN-PT). Kekuasaan penuh tetap berada di tangan BAN-PT dengan 15 orang anggota

\footnotetext{
${ }^{19}$ Bersama anggota tim lainnya dari fakultas/prodi pada sebuah perguruan tinggi, penulis pernah mengikuti langsung proses akreditasi sejak pengisian borang/portofolio/evaluasi diri sampai dengan visitasi. Banyak hal yang berharga dan menjadi pengalaman yang "indah" selama bergumul dengan proses akreditasi.
} 
majelisnya. Artinya, hasil akhir nilai akreditasi tidak diputuskan oleh satu orang, tetapi secara bersama atau kolektif oleh 15 anggota majelis tersebut. ${ }^{20}$

\section{Model Akreditasi PT Setelah 2012}

Sejak diberlakukanya Undang-Undang Republik Indonesia No. 12 Tahun 2012 tentang Pendidikan Tinggi, terjadi penyesuaian regulasi dan instrumen akreditasi. Berikut adalah dasar hukum kebijakan akreditasi perguruan tinggi setelah disesuaikaan dengan perkembangan regulasi. $^{21}$

a) Undang-Undang Nomor 12 Tahun 2012 tentang Pendidikan Tinggi;

b) Peraturan Pemerintah Nomor 4 Tahun 2014 tentang Penyelenggaraan Pendidikan Tinggi dan Pengelolaan Perguruan Tinggi;

c) Peraturan Presiden Nomor 8 Tahun 2012 tentang Kerangka Kualifikasi Nasional Indonesia;

d) Peraturan Menteri Pendidikan dan Kebudayaan Republik Indonesia Nomor 73 Tahun 2013 tentang Penerapan Kerangka Kualifikasi Nasional Indonesia Bidang Pendidikan Tinggi;

e) Peraturan Menteri Riset, Teknologi, dan Pendidikan Tinggi Nomor 44 Tahun 2015 tentang Standar Nasional Pendidikan Tinggi sebagaimana telah diubah dengan Peraturan Menteri Riset, Teknologi, Dan Pendidikan Tinggi Nomor 50 Tahun 2018 Tentang Perubahan Atas Peraturan Menteri Riset, Teknologi, dan Pendidikan Tinggi Nomor 44 Tahun 2015 tentang Standar Nasional Pendidikan Tinggi;

f) Peraturan Menteri Riset Teknologi dan Pendidikan Tinggi Nomor 32 Tahun 2016 tentang Akreditasi Program Studi dan Perguruan Tinggi;

g) Peraturan Menteri Riset Teknologi dan Pendidikan Tinggi Nomor 62 Tahun 2016 tentang Sistem Penjaminan Mutu Pendidikan Tinggi;

${ }^{20}$ http://edukasi.kompas.com/read/2010/10/22/20503740/BAN.PT.Menilai..BSNP.yang.Putuskan, diakses $12-13 / 1 / 2011$.

${ }^{21}$ Lampiran Peraturan Badan Akreditasi Nasional Perguruan Tinggi Nomor 3 tahun 2019 tentang Instrumen Akreditasi Perguruan Tinggi. 
h) Peraturan Menteri Riset, Teknologi, Dan Pendidikan Tinggi Nomor 51 Tahun 2018 tentang Pendirian, Perubahan, Pembubaran Perguruan Tinggi Negeri, dan Pendirian, Perubahan, Pencabutan Izin Perguruan Tinggi Swasta.

Setelah diberlakukannya UU RI No 12 tahun 2012 tentang Pendidikan Tinggi, kebijakan pendidikan tinggi, termasuk akreditasi, terlihat lebih terarah namun cenderung bersifat teknis-administratif dan diskursif. Berdasarkan Undang-undang tersebut, Sistem Penjaminan Mutu Pendidikan Tinggi (SPM-Dikti) diperkokoh melalui sistem penjaminan mutu internal (SPMI) oleh perguruan tinggi dan sistem penjaminan mutu ekseternal (SPME) melalui akreditasi. Artinya, keterjaminan mutu pendidikan tinggi bergantung pada SPMI. Sedangkan akreditasi hanyalah sebuah legitimasi dan rekognisi dari lembaga akreditasi sebagai konsekuensi logis dari pencapaian SPMI. Dengan demikian, mutu pendidikan tinggi secara substantif berada pada keefektifan dan keakuratan dari pelaksanaan SPMI.

Implementasi kebijakan akreditasi melalui penguatan model SPMI tersebut telah mendorong SPME melalui akreditasi oleh BAN-PT maupun oleh lembaga akreditasi lain yang diakui, termasuk oleh Lembaga Akreditasi Mandiri (LAM) maupun lembaga akreditasi internasional. Dan memang, setelah BAN-PT berhasil melaksanakan akreditasi institusi (AIPT), beberapa perguruan tinggi dapat memfokuskan pada capaan akreditasi internasional. Misalnya akreditasi untuk sekolah atau studi di bidang bisnis oleh Association to Advance Collegiate Schools of Business (AACSB) dari Amerika Serikat. Dalam hal ini, Fakultas Ekonomi dan Bisnis Universitas Gadjah Mada (FEB-UGM) berhasil memperoleh akreditasi dari AACSB sebagai perguruan tinggi pertama di Indomesia (2014), dan lima tahun kemudian diikuti oleh Binus Business School, Universitas Bina Nusantara (2019). Hanya sedikit atau tidak lebih dari 5\% dari jumlah sekolah bisnis di seluruh dunia yang berhasil memperoleh pengakuan dari lembaga tersebut. Di sanping itu, capaian Institut Teknologi Bandung (ITB) juga sangat membanggakan karena banyak program studi (lebih 80\%) yang diselenggarakannya berhasil memperoleh akreditasi internasional. 
Sampai akhir tahun 2017, jumlah perguruan tinggi di Indonesia secara keseluruhan sebanyak 4.590 perguruan tinggi. Jumlah tersebut terdiri dari berbagai bentuk perguruan tinggi, yaitu universitas (571), institut (186), sekolah tinggi (2.470), politeknik (258), akademi (1.090), dan akademi komunitas (15). Sedangkan program studi secara keseluruhan berjumlah 26.231 program studi. ${ }^{22}$ Sebanyak ribuan perguruan tinggi dan ribuan program studi itulah yang harus diakreditasi oleh BAN-PT.

Dengan anggaran biaya dan sumber daya manusia yang terbatas, kewenangan dan tanggung jawab yang dipikul BAN-PT luar biasa besar. Beruntung Lembaga Akreditasi Mandiri (LAM) seperti LAM untuk Pendidikan Tinggi Kesehatan (Kedokteran, Kedokteran Gigi, Keperawatan, Kebidanan, Gizi, Farmasi, dan Kesehatan Masyarakat) telah berhasil dibentuk (LAM-PTKes) dan sejak Maret 2015 sudah beroperasi. ${ }^{23}$ LAMPTKes dapat menjadi role model LAM untuk akreditasi program studi maupun profesi lain di Indonesia. Dengan beroperasinya LAM-PTKes, beban pekerjaan BAN-PT dapat terbantu.

Mendasarkan pada tujuh standar akreditasi BAN-PT, hasil penelitian Sutopo dkk (2019) menyimpulkan bahwa peringkat A untuk akreditasi program studi pada Perguruan Tinggi Swasta (PTS) masih didominasi oleh perguruan tinggi dari Pulau Jawa yang tersebar dalam lima provinsi, yaitu Yogyakarta (32\%), DKI Jakarta (18\%), Jawa Barat (18\%), Jawa Timur (13\%), dan Jawa Tengah (12\%). Secara keseluruhan, peringkat A untuk akreditasi program studi di lima povinsi tersebut tidak lebih dari 10\%. Jika dibandingkan dengan provinsi di luar Pulau Jawa, capaian tersebut sudah cukup lumayan. Karena, bahkan untuk banyak provinsi, tidak satupun program studi yang mampu memperoleh akredtasi pada peringkat A. Penelitian ini telah mengkonfirnasi bahwa kesenjangan mutu pendidikan tinggi antara Jawa dan luar Jawa memang nyata adanya.

\footnotetext{
${ }^{22}$ Laporan Tahunan Eksekutif BAN-PT Tahun 2017, berdasarkan data dari www.forlap.ristekdikti.go.id.

${ }^{23}$ https://lamptkes.org/Profil, diakses 25 Juni 2021.
} 
Pada tahun 2019, BAN-PT mengembangkan model baru (9 kriteria/standar) untuk akreditasi program studi/perguruan tingi. ${ }^{24}$ Model ini lebih difokuskan pada pencapaian output dan outcome program studi/perguruan tingg ketimbang pada aspek input dan proses administratif. Dengan model 2019, standar dan kriteria penilaiannya juga turut berubah. Pendeknya, istrumennya juga turut berubah karena yang menjadi fokus juga berubah, yaitu pengukuran terhadap tingkat luaran dan capaian Tridharma Perguruan Tinggi. Dan memang, akreditasi untuk program pendidikan (program studi) berkenaan dengan penilaian terhadap proses pembelajaran lebih pada isian tentang persyaratan dan sasaran/capaian pembelajaran, proses pengajaran-pembelajaran, dan sumber pembelajaran. Modalnya diserahkan pada masing-masing perguruan tinggi (Heidari \& Arnold, 2021).

Dalam borang akreditasi model 2019, data kuantitatif sangat menonjol digunakan untuk memudahkan penilaian, sebagaimana terdapat pada borang Laporan Kinerja Program Studi (LKPS). Data LPKS itulah, bagi penyelenggara program studi, yang semestinya menjadi dasar dalam penyusunan Laporan Evaluasi Diri (LED), di samping analisis lingkungan eksternal. Data LKPS memiliki implikasi yang luas pada penyelenggaraan program sudi/pendidikan tinggi. Jika validitas data LKPS dapat diandalkan, maka ke depan akreditasi program studi maupun secara akumulatif untuk kepentingan akreditasi perguruan tinggi (institusi) akan lebih mudah dipersiapkan.

\section{Belajar dari Pengalaman}

Belajar dari capaian akreditasi sepuluh tahun terakhir (2009-2019), termasuk pada masa transisi dari tujuh standar menjadi sembilan standar/kriteria per April 2019, penting dilakukan. Apalagi ketika muncul "tsunami borang" akreditasi program studi yang telah menyibukkan sebagian perguruan tinggi dan terutama BAN-PT. Kala itu banyak program studi berpacu untuk dapat diakreditasi atau direakreditasi menggunakan cara lama, model tujuh standar. Agaknya kebijakan BAN-PT tersebut belum sepenuhnya diantisipasi

\footnotetext{
${ }^{24}$ Lampiran Peraturan Badan Akreditasi Nasional Perguruan Tinggi Nomor 2 tahun 2019 tentang Panduan Penyusunan Laporan Evaluasi Diri dan Panduan Penyusunan Laporan Kinerja Program Studi dalam Instrumen Akreditasi Program Studi. Jakarta: BAN-PT, 2019.
} 
sehingga anggaran BAN-PT tidak mencukupi untuk melaksanakan visitasi atau esesman lapangan.

Pada masa-masa sebelumnya, ketika semua program studi harus terakreditasi sesuai dengan Peraturan Pemerintah Nomor 15 Tahun 2005, yang seharusnya sudah berlaku sejak tahun 2012, juga terjadi penumpukan dan keterlambatan. Pada tahun 2010 misalnya, menurut Fasli Jalal (Wakil Mendiknas ketika itu), sebanyak 6.000 dari total 15.600 program studi yang ada di perguruan tinggi, baik negeri maupun swasta, belum terakreditasi. Tahun 2010 ditargetkan ada 4.000 program studi yang akan diakreditasi, sisanya ditargetkan terakreditasi pada 2011. Jika masih ada program studi yang belum terakreditasi, mulai tahun 2012 program studi yang tidak terakreditasi akan ditutup. ${ }^{25}$

Untuk mencapai target tersebut, pada tahun 2010 pemerintah menganggarkan biaya sebesar Rp 22 juta per program studi untuk 4.000 program studi. ${ }^{26}$ Sebagian besar program studi yang belum terakreditasi itu ada di perguruan tinggi swasta. Hanya sebagian kecil program studi di perguruan tinggi negeri yang belum terakreditasi, kurang dari lima persen. Umumnya, yang belum terakreditasi pada PTN itu adalah program studi baru. ${ }^{27}$ Sementara itu, untuk akreditasi institusi dari 3.000 perguruan tinggi yang terdaftar, baru 78 yang terakreditasi. ${ }^{28}$

Kenyataan pada masa itu, sebagaimana dikemukakan oleh Suharyadi (Ketua APTISI), terlihat sangat rumit. Karena jumlah perguruan tinggi dan program studi sangat banyak, sementara BAN-PT hanya ada satu. ${ }^{29}$ Tampaknya kinerja BAN-PT mulai tidak memuaskan perguruan tinggi dan masyarakat. BAN-PT sebagai satu-satunya institusi

\footnotetext{
25 http://edukasi.kompas.com/read/2010/02/17/08022429/6.000.Program.Studi.Belum.Terakreditasi, diakses 12/1/2011.

${ }^{26}$ http://edukasi.kompas.com/read/2010/02/17/08022429/6.000.Program.Studi.Belum.Terakreditasi, diakses 12/1/2011.

${ }^{27}$ http://edukasi.kompas.com/read/2009/12/24/1735103/Program.Studi.Tidak.Terakreditasi.Segera.Ditutup.. , diakses 12/11/2011.

${ }^{28}$ http://edukasi.kompas.com/read/2010/10/22/1912219/1.500.Program.Studi.Belum.Terakreditasi, diakses $12 / 1 / 2011$.

${ }^{29}$ http://edukasi.kompas.com/read/2010/10/25/17334689/Terlalu.Rumit.Mengakreditasi.Semuanya, diakses 12/1/2011
} 
akreditasi perguruan tinggi yang diakui pemerintah dinilai lamban menuntaskan akreditasi semua program studi di perguruan tinggi negeri dan swasta. ${ }^{30}$

Ketika itu, meskipun masih ada waktu sekitar 2 tahun sampai dengan tahun 2012, target kebijakan akreditasi sulit dicapai. Bukan hanya disebabkan oleh BAN-PT saja, tetapi juga oleh faktor internal perguruan tinggi yang bersangkutan. Terutama untuk perguruan tinggi swasta (PTS), kebijkan akreditasi masih menjadi beban. Bahkan juga untuk sebagian perguruan tinggi negeri (PTN). Masih terdapatnya 2.788 program studi yang akreditasinya telah kadaluwarsa baik di PTN maupun di PTS, ${ }^{31}$ semakin menunjukkan bahwa kebijakan akreditasi masih menjadi beban. Bila jumlah program studi yang belum terakreditasi ditambah dengan program studi yang akreditasinya telah kadaluwarsa, maka pekerjaan untuk mencapai target di semakin banyak. Jadi, pelaksanaan kebijakan akreditasi perguruan tinggi, dari sisi target dan tujuan, agaknya belum tercapai.

Bagaimana respons perguruan tinggi swasta (PTS) terhadap kinerja Badan Akreditasi Nasional Perguruan Tinggi (BAN-PT) pada masa itu? Bila pada tahun 1997 sekitar $24 \%$ program studi PTS terakreditasi A, saat ini justru mengalami penurunan tinggal $8 \%{ }^{32}$ Data ini tentu menimbulkan pertanyaan, apalagi jika hanya peringkat akreditasi tersebut yang menjadi parameternya. Ini berarti lebih dari 10 tahun kinerja PTS justru merosot tajam. Tetapi yang jelas data ini mengindikasikan adanya hambatan ataupun kendala pelaksanaan akreditasi, khususnya bagi PTS.

Harus diakui memang, keadaan PTS tidaklah sama bahkan sangat beragam. PTS yang ada di Pulau Jawa saja beragam, apalagi di luar Pulau Jawa. Jika kita bersedia mengakui secara jujur, pada PTN juga mengalami hal yang sama. Artinya, jika standar yang ditetapkan BAN-PT sama untuk semua perguruan tinggi, maka yang paling

\footnotetext{
30 http://edukasi.kompas.com/read/2010/10/26/0759305/Akreditasi.Lamban..Mahasiwa.Kena.Imbas, diakses 12/1/2011.

31 Lihat, http://www.wartakampus.com/index.php?option=com_content\&view=article\&id=60:ribuanakreditasi-program-studi-pt-kedaluwarsa\&catid=25:prestasi diakses 21/1/2011.

${ }^{32}$ Lihat,http://edukasi.kompas.com/read/2010/08/13/21494388/APTISI..Kenaikan.Standar.Akreditasi.Diduk ung.Pranata, diakses 12/1/2011.
} 
dirugikan adalah perguruan tinggi di daerah tertinggal. ${ }^{33}$ Ada kesan BAN-PT tidak transparan dan tidak obyektif dalam menilai suatu program studi. ${ }^{34}$ Akibatnya, Asosiasi Perguruan Tinggi Swasta Indonesia (APTISI) menolak badan akreditasi nasional perguruan tinggi (BAN-PT) sebagai satu-satunya badan akreditasi nasional bagi perguruan tinggi. BAN-PT saat ini dinilai tidak kompeten lagi menangani akreditasi program studi seluruh perguruan tinggi dengan obyektif, transparan, terbuka, serta komprehensif. ${ }^{35}$

Asosiasi Perguruan Tinggi Indonesia (APTISI) mengeluhkan naiknya standar akreditasi perguruan tinggi yang belum didukung dengan pranata atau bantuan peningkatan kualitas perguruan tinggi swasta dari pemerintah. ${ }^{36}$ Tanpa didukung pranata, menurut Budi Djatmiko, maka perguruan tinggi swasta khususnya di daerah-daerah akan semakin sulit meningkatkan akreditasnya. Menurutnya, kalau tetap seperti sekarang, perguruan tinggi besar saja yang hanya bisa diakreditasi. Kalau perguruan tinggi di daerah-daerah susah sekali mendapatkan akreditasi C. ${ }^{37}$

Tetapi, menurut Eduardus dari BAN-PT, banyak program studi saat ini yang menurut data tampak bagus. Namun, setelah dilakukan pengecekan di lapangan hasilnya kerap tidak memuaskan. Penilaian lapangan tersebut, menurutnya, dilakukan oleh tim asesor dengan mewawancarai dosen, mahasiswa, serta alumni. Menurut Eduardus, BAN-

\footnotetext{
${ }^{33}$ http://edukasi.kompas.com/read/2010/08/13/20142873/Mendiknas.Didesak.Bentuk.Badan.Akreditasi.Lai n, diakses tgl 12/1/2011."Akreditasi ini ditekankan untuk mengarahkan PTS sebagai world class of university tetapi semua standarnya disamakan. Lha, bagaimana PTS yang ada di daerah. Teman-teman kami yang di Papua tentu saja teriak tidak sanggup," ujar Rektor Universitas Mercu Buana ini. "Ada asesor (personalia BAN PT) yang menggunakan standar luar negeri untuk mengakreditasi perguruan tinggi daerah," ujar Ketua APTISI Jawa Barat, Budi Djatmiko.

${ }^{34}$ http://edukasi.kompas.com/read/2010/08/13/20142873/Mendiknas.Didesak.Bentuk.Badan.Akreditasi.Lai

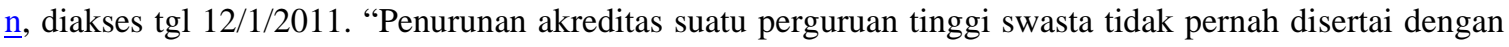
alasan yang kuat. "Tidak ada kesempatan bertanya akreditasi A sekarang B, karena apa. Harusnya ada kesempatan kita untuk berdiskusi, berdialog,"

${ }^{35} \mathrm{http} / / /$ edukasi.kompas.com/read/2010/08/13/22471977/Akreditasi.PTS.Terlalu.Dipaksakan, diakes $12 / 1 / 2011$.

${ }^{36}$ http://edukasi.kompas.com/read/2010/08/13/21494388/APTISI..Kenaikan.Standar.Akreditasi.Didukung.P ranata, diakses 12/1/2011.

${ }^{37} \mathrm{http}$ ://edukasi.kompas.com/read/2010/10/22/20503740/BAN.PT.Menilai..BSNP.yang.Putuskan, diakses $12-13 / 1 / 2011$.
} 
PT tidak asal memberi penilaian, sebab harus ada uraian yang jelas juga. Di samping itu, hasil kerja asesor juga akan dievaluasi. ${ }^{38}$

Bagi PTN penurunan peringkat akreditasi terhadap sejumlah program studi yang dibinanya, tidak berimplikasi serius. Masyarakat tetap akan menganggap PTN lebih bermutu daripada PTS. Tetapi bagi PTS akreditasi adalah persoalan hidup dan mati. Misalnya, pengalaman penulis diprotes oleh mahasiswa dan perwakilan alumni karena mereka tidak dapat mendaftar menjadi CPNS Pemda dikarenakan akreditasi yang dipersayaratkan adalah $\mathrm{A}$.

Alhamdulillah setelah dijelaskan persoalan tersebut dapat diatasi dan bahkan beberapa dari mereka berhasil menjadi PNS. Tetapi biaya sosialnya besar karena telanjur menyebar sehingga memengaruhi minat calon mahasiswa baru. Betapa hebohnya bila hal semacam ini terjadi di seluruh wilayah Indonesia. Masyarakat akan resah, dan PTS pun segera tutup. Hal ini menunjukkan bahwa kebijakan apa pun, apalagi kebijakan pendidikan yang menyangkut masa depan warga negara, harus memperhatikan para pemangku kepentingan secara luas (stakeholders).

Kinerja Badan Akreditasi Nasional Perguruan Tinggi (BAN-PT) mulai tidak memuaskan perguruan tinggi dan masyarakat. BAN-PT sebagai satu-satunya institusi akreditasi perguruan tinggi yang diakui pemerintah dinilai lamban menuntaskan akreditasi semua program studi di perguruan tinggi negeri dan swasta. ${ }^{39}$ Oleh karena itu, menarik apa yang disampaikan oleh Asosiasi Perguruan Tinggi Swasta Indonesia (APTISI) yang mendesak Menteri Pendidikan Nasional Muhammad Nuh, agar segera menginjinkan adanya badan akreditasi lain selain Badan Akreditasi Nasional (BAN) Perguruan Tinggi. Karena menurut Ketua APTISI, BAN PT yang ada saat ini tidak

\footnotetext{
${ }^{38}$ http://edukasi.kompas.com/read/2010/10/22/20503740/BAN.PT.Menilai..BSNP.yang.Putuskan, diakses $12-13 / 1 / 2011$

${ }^{39} \mathrm{http} / / /$ edukasi.kompas.com/read/2010/10/26/0759305/Akreditasi.Lamban..Mahasiwa.Kena.Imbas, diakses 12/1/2011.
} 
mampu menangani akredikasi program studi seluruh Perguruan Tinggi secara obyektif, transparan, terbuka, dan komprehensif. ${ }^{40}$

Belajar dari pengalaman tersebut di atas, munculnya kebijakan MBKM (Permendikbud Nomor 3 Tahun 2020), patut disyukuri dan semestinya diapresiasi. Melalui kebijakan Mas Menteri Nadiem tersebut, saat ini perguruan tinggi memiliki keleluasaan dan pilihan dalam meningkatkan mutu pendidikannya. Perguruan tinggi tidak lagi terbebani dengan urusan teknis administratif birokratis. Suatu masalah yang sudah lama menggelisahkan kaum intelektual dan sudah banyak disampaikan oleh banyak pimpinan perguruan tinggi. Kini, perguruan tinggi dapat berfokus pada peningkatan mutu pembelajaran secara substantif. Apalagi jika antar-perguruan tinggi dan industri dapat berkolaborasi, kebijakan MBKM tersebut akan banyak memberi arti bagi peningkatan mutu pendidikan tinggi.

Bayangkan, setiap tahun sekitar 1,7 sarjana baru diluluskan dari perguruan tinggi kita yang belum merata kualitasnya. Hasilnya adalah sebuah ketimpangan. Dengan kebijakan MBKM alokasi asset dan sumberdaya dapat dilakukan secara lebih efisien dan efektif untuk pemerataan mutu pendidikan tinggi. Syaratnya, harus ada kesediaan dan kesiapan dari semua pihak, dari semua pemangku kepentingan, bahwa pendidikan adalah hak setiap warga negara Indonesia tanpa memandang status. Sudah terlalu lama asset dan sumber daya pendidikan tinggi dan perguruan tinggi kita dikuasai dan dinikmati hanya oleh sekelompok warga negara yang, belum sepenuhnya disadari, hanya menjadi perpanjangan tangan dan bentuk baru dari feodalisme masa kolonial.

\section{Implikasi Kebijakan MBKM}

Memperhatikan pengalaman akreditasi oleh BAN-PT dan kebijakan MBKM pada aspek akreditasi dan kesempatan mahasiswa untuk belajar selama tiga semester pada program studi lain, sebagaimana telah dijelaskan di muka, maka akan berimplikasi pada manajemen perguruan tinggi dan kurikulum program studi: Pertama, manajemen perguruan tinggi dan penyelenggaraan pendidikan tinggi. Perguruan tinggi harus

\footnotetext{
${ }^{40}$ http://edukasi.kompas.com/read/2010/08/13/20142873/Mendiknas.Didesak.Bentuk.Badan.Akreditasi.Lai n, diakses tgl 12/1/2011.
} 
mempersiapkan dosen atau pengajarnya dan mahasiswanya agar sesuai dengan tuntutan kebijakan MBKM yang bercorak industri. Bagi perguruan tinggi negeri (PTN) dan perguruan tinggi swasta (PTS) milik konglomerat jelas tidak ada persoalan. Mereka memiliki sumberdaya manusia dan sumberdaya lainnya yang terkoneksi langsung dengan dunia industri nasional bahkan internasional. Jika orientasinya adalah industri seperti saat ini, maka PTS yang mayoritas kecil akan kesulitan dalam pembiayaan yang berujung pada beban biaya bagi orang tua mahasiswa. Kecuali pemerintah memfasilitasi kerja sama antara kalangan industri dan PTS. Pemerintah harus mampu mendorong dunia industri untuk turut berkontribusi pada sektor pendidikan, bukan sebaliknya termanfaatkan untuk memperbesar pengaruh dalam jaringan bisnisnya. Pasti ke depan delapan jalur kegiatan mahasiswa dalam konteks MBKM akan berjalan dan dijalankan oleh semua perguruan tinggi dengan beragam cara. Tetapi jika oritentasinya adalah industri, mitra internasional, rekognisi internasional, perlu butuh waktu dan biaya serta insentif dari pemerintah yang harus didistribusikan secara adil dan proporsional. Harus diingat, ribuan jumlah PTS di Indonesia mayoritas kecil secara finansial. Dalam hal ini, sumberdaya dan asset PTN yang selama ini belum optimal dapat diakses oleh mahasiswa PTS yang membutuhkan bantuan dan pertolongan, seharusnya dapat dioptimalkan secara inklusif. Model MBKM memungkinan untuk itu.

Kedua, kurikulum yang menyediakan kesempatan mahasiswa untuk mengambil mata kuliah pada program studi lain atau pada perguruan tinggi lain selama tiga semester. Ini sebuah terobosan menarik jika ada kerja sama dari semua pihak, sebagaimana poin pertama. Sebuah alternatif dapat diajukan di sini. Misalnya selama lima semester pertama mahasiswa hanya belajar sesuai dengan kurikulum utama program studi. Secara administrasi pada tahapan ini tidak sulit dilakukan. Tantangannya adalah mulai semester keenam sampai selesai (semester delapan) karena harus mempertimbangkan minat, bakat, dan kemampuan mahasiswa serta pihak lain. Pihak lain bisa dari internal kampus tetapi juga bisa dari eksternal kampus. Di sinilah dibutuhkan perspektif pendidikan tinggi sekaligus kemampuan manajerial dan komunikasi kepada pihak lain. Konsekuensinya adalah biaya dan urusan teknis administrasi seperti penyesuaian jadwal kuliah dan biaya 
kuliah yang beragam. Terlihat perguruan tinggi "kelas dunia" sudah mulai pasang badan: "Mahasiswa dari luar harus melalui tes!" Tidak salah. Boleh jadi mahasiswa dari "luar dunia" itu hanya ingin mencicipi kampus "kelas dunia" di negerinya sendiri. Memang kebijakan MBKM Mas Menteri Nadiem menarik dan relevan sebagai alternatif solusi pendidikan abad 21. Meskipun tantangannya masih sama, yaitu eksklusifisme dan feodalisme.

\section{E. Kesimpulan}

1. Sampai akhir tahun 2019 atau sebelum terbitnya Permendikbud nomor 3 tahun 2020, kebijakan akreditasi perguruan tinggi di Indonesia, baik akreditasi untuk program studi maupun akreditasi untuk institusi, masih menggunakan pendekatan dari atas (top down), bercorak sentralistik, dan bersifat wajib (mandatory). Sebab, kebijakan akreditasi muncul dari inisiatif pemerintah bukan atas dasar kesadaran (suka rela) dari pengelola perguruan tinggi dan penyelenggara pendidikan tinggi. Akibatnya, ketika terjadi penumpukan berkas borang akreditasi baik yang berbentuk manual maupun digital (online) pada BAN-PT, tidak lagi mampu diproses sesuai jadwal. Implikasinya sudah sama-sama diketahui bagi perguruan tinggi dan juga bagi masyarakat, terlampau mahal biaya sosial yang ditimbulkan.

2. Secara kuantitas, seluruh target akreditasi sebelum maupun setelah tahun 2012 tidak dapat tercapai. Menjelang tahun 2012, sebanyak 6.000 dari total 15.600 program studi, baik negeri maupun swasta, belum terakreditasi. Ditambah lagi masih terdapat 2.788 program studi yang akreditasinya telah kadaluwarsa baik di PTN maupun di PTS. Saat ini, setelah hampir sepuluh tahun berlalu dari 2012, keadaannya masih nyaris sama, terutama pada masa transisi implementasi kebijakan borang akreditasi dari 7 (tujuh) standar menjadi 9 (sembilan) standar/kriteria pada April 2019. Di samping disebabkan oleh keterbatasan anggaran dan pandemi Covid-19, juga karena sebuah kenyataan bahwa sebagian besar perguruan tinggi kita belum siap menggunakan model 9 standar/kriteria. Dengan kata lain, keterlambatan proses akreditasi bukan hanya disebabkan oleh BAN-PT saja, tetapi juga oleh faktor internal perguruan tinggi yang bersangkutan. 
Terutama untuk mayoritas perguruan tinggi swasta (PTS). Sebab, di samping jumlahnya banyak, profil dan kinerja PTS juga sangat beragam.

3. Implementasi kebijakan pendidikan tinggi seringkali kurang konsisten. Misalnya terjadi pada kebijakan moratorium untuk pembentukan program studi baru atau pendirian perguruan tinggi baru. Inkonsistensi dalam kebijakan moratorioum akan banyak melahirkan pekerjaan rumah di masa kini dan kemungkinan besar di masa mendatang, terutama dalam pencapaian standar mutu pendidikan tinggi. Akibatnya, segala upaya untuk mengejar ketertinggalan hasilnya benar-benar tertinggal. Bukan rahasia lagi bahwa secara substantif mutu pendidikan tinggi nasional kita kurang memiliki daya inovasi berhadapan dengan tantangan zaman..

4. Kebijakan Merdeka Belajar-Kampus Merdeka (MBKM) yang dipaketkan dengan kebijakan akreditasi, baik untuk program studi maupun untuk institusi perguruan tinggi, merupakan sebuah terobosan yang berani dan banyak arti. Sebuah kebijakan yang memberi harapan dan mudah dipahami oleh masyarakat pendidikan tinggi, terutama bagi mereka yang sudah lama berkubang dengan urusan administrasi dan birokrasi. Kebijakan MBKM telah menyadarkan adanya salah kaprah dalam tata kelola perguruan tinggi, di mana alat dan tujuan dianggap sebanding. Sekali lagi, akreditasi hanyalah alat bukan tujuan.

5. Dengan kebijakan MBKM tersebut, semua pemangku kepentingan utama pendidikan tinggi boleh merasa lega. Sudah lama dirasakan oleh pihak orang tua dan peserta didik (mahasiswa) bahwa biaya pengetahuan terasa terlalu mahal, baik untuk ongkos maupun waktu. Apalagi jika yang diajarkan tidak dibutuhkan, dan yang dubutuhkan justru tidak diajarkan. Sedangkan bagi pengelola dan penyelenggara pendidikan, beban pekerjaan administrasi yang sebelumnya terasa lebih menyita dan menyedot sumber daya, akan lebih berdaya guna untuk peningkatan mutu secara substantif dan relevan untuk kepentingan hidup dan penghidupan calon lulusan. Inti dari kebijakan MBKM tidak lain adalah, bagaimana agar perguruan tinggi mampu beradaptasi dengan perkembangan masyarakat industri dalam konteks global untuk kepentingan nasional. 
Masyarakat industri dicirikan oleh obyektivikasi, kompetensi, inovasi, dan rasionalitas ekonomi. Di situlah menariknya bahwa kebijakan MBKM dan akreditasi telah tepat mengenai sasaran. Tinggal bagaimana implementasinya. Semoga.

\section{Referensi:}

Cooper, Bruce S., James G. Cibulka, dan Lance D. Fusarelli. 2008. Handbook of Education Politics and Policy, New York \& London: Routledge.

Hasbullah. 2010. Otonomi Pendidikan: Kebijakan Otonomi Daerah dan Implikasinya terhadap Penyelenggaraan Pendidikan, Jakarta: Rajagrafindo Persada.

Hegji, Alexandra. 2020. An Overview of Accreditation of Higher Education in the United States. Congressional Research Service. R43826. (October 16) https://crsreports.congress.gov

Heidari M., Arnold O. 2021. Toward Process Variability Management in Online Examination Process in German Universities: A State of the Art. In: Koschtial C., Köhler T., Felden C. (eds) e-Science. Progress in IS. Springer, Cham. https://doi.org/10.1007/978-3-030-66262-2_8

Ladd, Helen F., dan Edward B. Fiske (Eds). 2008. Handbook of Research in Education Finance and Policy, New York \& London: Routledge.

Peraturan Mendiknas No. 28 Tahun 2005 tentang BAN-PT.

Peraturan Pemerintah RI. No. 19 Tahun 2005 tentang Standar Nasional Pendidikan.

Permendikbud Nomor 3 Tahun 2020 tentang Standar Nasional Pendidikan Tinggi.

Rencana Strategis Kementerian Pendidikan dan Kebudayaan 2020-2024.

Sallis, Edward. 2002. Total Quality Management in Education, London: Routledge.

Sirozi, Muhammad. 2004. Politik Kebijakan Pendidikan di Indonesia, Jakarta: INISLeiden-Jakarta.

Sunarto, Kamanto. 2009. Kebijakan BAN-PT 2006-2011 (Bahan Presentasi), Jakarta: BAN-PT. 
Surakhmad, Winarno. 2009. Pendidikan Nasional; Strategi dan Tragedi. Jakarta: Kompas.

Sutopo, Sugiyono, dan Bayu Rahmat Setiyadi. 2019. Analysis of the Accreditation Grade of Study Programs of Higher Education in Indonesia. Advances in Social Science, Education and Humanities Research, volume 335. 1st International Conference on Education, Social Sciences and Humanities (ICESSHum 2019). Published by Atlantis Press.

Sywelem, M. \& Witte, J. 2009. Higher Education Accreditation in View of International Contemporary Attitudes. Contemporary Issues In Education Research: Spring 2009, Vol. 2, No. 2, pp. 41-54.

The Land-Grant Tradition. 2012. Washington DC: Association of Public and Land-Grant Universities.

Tilaar, H.A.R. 2009. Kekuasaan dan Pendidikan. Jakarta: Rineka Cipta.

Undand-Undang RI. No. 12 Tahun 2012 tentang Pendidikan Tinggi.

Undang Undang RI. No. 14 Tahun 2005 tentang Guru dan Dosen.

Undang-Undang RI. No. 20 Tahun 2003 tentang Sistem Pendidikan Nasional.

http://edukasi.kompas.com/read/2010/10/22/16215327/2.922.Perguruan.Tinggi.Tanpa.Akreditasi, diakses $12 / 1 / 2011$

http://edukasi.kompas.com/read/2010/02/17/08022429/6.000.Program.Studi.Belum.Terakreditasi, diakses $12 / 1 / 2011$

http://edukasi.kompas.com/read/2010/08/13/22471977/Akreditasi.PTS.Terlalu.Dipaksakan, diakes $12 / 1 / 2011$

http://edukasi.kompas.com/read/2009/12/24/1735103/Program.Studi.Tidak.Terakreditasi.Segera.Ditutup.., diakses 12/11/2011

http://edukasi.kompas.com/read/2010/08/13/21494388/APTISI..Kenaikan.Standar.Akreditasi.Didukung.Pra nata, diakses 12/1/2011

http://edukasi.kompas.com/read/2010/10/22/20503740/BAN.PT.Menilai..BSNP.yang.Putuskan, diakses 12$13 / 1 / 2011$

http://edukasi.kompas.com/read/2010/08/13/20142873/Mendiknas.Didesak.Bentuk.Badan.Akreditasi.Lain, diakses tgl 12/1/2011

http://edukasi.kompas.com/read/2010/10/26/0759305/Akreditasi.Lamban...Mahasiwa.Kena.Imbas, diakses $12 / 1 / 2011$

http://edukasi.kompas.com/read/2010/10/25/17334689/Terlalu.Rumit.Mengakreditasi.Semuanya, diakses $12 / 1 / 2011$ 